\title{
Development of Linear Program Programs for Teaching Materials with Collaborative Learning Assisted iSpring Presenter
}

\author{
Fhela Vhantoria Ningrum ${ }^{1}$, Venty Meilasar ${ }^{2}$ \\ (riavhantoria@gmail.com¹, ventymeilasari@gmail.com)
}

Prodi Pendidikan Matematika STKIP Muhammadiyah Kotabumi, Indonesia ${ }^{12}$

\begin{abstract}
The purpose of this research is to develop teaching material in the transportation problem of the linear program through collaborative learning approach assisted iSpring presenter with good advisability. This research is a development research of Borg \& Gall. The advisability of teaching material is looked from validation result of teaching material by experts and respondents' questionnaire related to teaching material. The result of the trial showed according to advisability test of questionnaire result percentage of students' response was $81,09 \%$ as a good category. Then supported by validation result of media expert with the percentage $74 \%$ as a good category, validation of language expert with the percentage $90 \%$ as a very good category, and validation of material with the percentage $75,20 \%$ as a good category. When all categories are more than equals to good, then teaching material is proper to be used. This research produces interactive learning media.
\end{abstract}

Keywords. Development Research, Teaching Material of Transportation Problem, Collaborative Learning, Ispring Presenter 


\section{Introduction}

The linear program is simple to model identification in management operation research. One of the problems in the linear program is the transportation problem. Transportation problem is used to develop the settlement procedure of efficient transportation technique. To solve the product distribution problem from some sources to some destination places optimally with minimum distribution fee. [1] in her research explained that generally transportation problem is related in product and service distribution from several production centers to the sale location. If the distribution is not appropriate, so it will spend many fees and waste much time. Meanwhile, distribution used transportation is much related. Therefore transportation problem becomes one of the problems solving which exists in the linear program

Based on students' response toward college activity of transportation problem teaching material is not interesting. Then most students have difficulty in deciding settlement of transportation problem. Furthermore, digital technology has applied in learning but it still does not yet help to explore students' intellectual in solving the problem.

Digital technology is such as video that has been using in the learning process. Therefore it needs to be applied a tool to record and synchronize video presenter, to add flash and YouTube video by making navigation and unique design. One of the tools that can be used is iSpring presenter. [2] which concluded that the use of iSpring presenter can increase motivation and achievement than using a conventional method that becomes one of the supports in deciding iSpring presenter as media that was used in this research.

Furthermore working activeness in learning becomes measure reference for learning quality. A learning is qualified if more than $75 \%$ of students involved actively. Collaborative learning approach is reputed able to solve students' difficulty because discussion can unite students' idea. In addition, the discussion can motivate students to be active in learning. It is appropriate with the advantage of collaborative learning which revealed [3] that it could develop a method of critical think and rational along with building teamwork among students and guiding students discussion.

\section{Research method}

Development research that is adapted from [4] is applied in this research. Through 10 steps procedure. This research was conducted in STKIP Muhammadiayah Kotabumi Lampung. The research subject of this research is 13 students of semester IV in mathematics study program of STKIP Muhammadiyah Kotabumi. Previously teaching material trial was done on 21 students of semester VI in mathematics study program STKIP Muhammadiyah Kotabumi with a reason that students had taken linear program subject related to the transportation problem.

[5] explained development research of Born and Gall then it is used by the researcher in developing teaching material of transportation problem through collaborative learning approach assisted iSpring presenter with these steps below:

\subsection{Research and Information Collecting}


This first step is including need analysis, book study, literature study, small-scale research and report standard that is needed.

\subsection{Planning}

In planning step, researcher arranges to teach material draft of linear program transportation, installation of iSpring presenter as applied learning media, and selection of collaborative learning model which is proper with its need.

\subsection{Develop Primary Form of Product}

In this step, book study becomes a measure reference of the draft making of teaching material which is proper with the development plan of the teaching material. It is related to the used model, and the steps of research implementation.

\subsection{Preliminary Field Testing}

In this step is conducted limited teaching material test that is teaching material validation. The validation is carried out to assess proposal of beginning teaching material rationally. The validation of teaching material is carried out by experts such as media expert language expert and material expert.

\subsection{Main Product Revision}

After conducting the validation of teaching material then the next step is revision according to suggestion result and opinion from the experts.

\subsection{Main Field Testing}

After teaching material is revised, the next step is teaching material is tested to 21 students of semester VI in mathematics study program of STKIP Muhammadiyah Kotabumi with a reason that the students had taken linear program subject related to the transportation problem. The purpose of Main Field Testing step is to find out advisability of teaching material.

\subsection{Operational Product Revision}

After the advisability test, then the next step is proposing questionnaire to get information related to students' response toward the development of teaching material. However, the questionnaire must be tested its validity and reliability first.

\subsection{Operational Field Testing}

The next step is a trial test to 13 students of semester IV in mathematics study program of STKIP Muhammadiyah Kotabumi because the subject of the linear program about transportation problem is lectured in that semester.

\subsection{Final Product Revision}

In this step, teaching material is completed through suggestion or second advisability test based on the response from students of semester IV.

\subsection{Dissemination and Implementation}


Dissemination and Implementation are reporting teaching material to the professional forums in the journal and implementing teaching material to the linear program subject on the next year. Publishing teaching material is to be distributed freely to be used by public or colleague of STKIP Muhammadiyah Kotabumi library. Periodic monitoring is constantly conducted to keep teaching material quality.

\section{Data collecting technique}

The data source in this research was validation result from the experts and students' response toward teaching material. Besides, there were additional data such as result of spring presenter, and activity documentation. Validation data of expert team consisted of media, material and language expert. The next is data of students' respondent. Data collecting instruments consisted of questionnaire and observation sheet. The questionnaire contained some statements about the quality of teaching material based on language material and media aspect. Then the observation sheet contained statements about learning process happen. Assessment of questionnaire result used a Likert scale with scale 5 is meant positive and meant negative.

\section{Data analysis}

\subsection{Analysis of expert team validation result}

Technical steps of analysis data of expert team validation are changing qualitative data research that was conversed to quantitative data, counting assessment average score, and counting the ideal percentage.

\subsection{Analysis of student respondents}

Before students' response was carried out, the calculation of internal consistency was carried out first and the reliability as data analysis requirement. Internal Consistency of point-i could be counted by using the formula of product correlation from Karl Pearson. Test point would be used if it had an index of internal consistency $r_{x y} \geq 0,3$. This index of internal consistency was often called distinguishing power [6]. The next counting is Reliability which used Alpha formula to do reliability test. An instrument was said reliable if $r_{11}>0,7$.

The data analysis was revealed through the steps are students' response value analysis toward teaching material was got percentage result. Then it is categorized based on score interval. These are table 1 and 2 which is related to interpretation criteria of Expert Validation and Students' response that is adapted from [7].

Table 1. Interpretation Criteria of Expert Validation

\begin{tabular}{|c|c|}
\hline Percentage & Interpretation Criteria \\
\hline $0-20$ & Very Not Good \\
\hline
\end{tabular}




\begin{tabular}{|c|c|}
\hline $21-40$ & Not Good \\
\hline $41-60$ & Quite Good \\
\hline $61-80$ & Good \\
\hline $81-100$ & Very Good \\
\hline
\end{tabular}

Table 2. Interpretation Criteria of Students' Response

\begin{tabular}{|c|c|}
\hline Percentage & Interpretation Criteria \\
\hline $0-20$ & Very Not Good \\
\hline $21-40$ & Not Good \\
\hline $41-60$ & Quite Good \\
\hline $61-80$ & Good \\
\hline $81-100$ & Very Good \\
\hline
\end{tabular}

\section{$5 \quad$ Result and discussion}

Research result consists of validation result of the expert team and result of students' response questionnaire related to teaching material. Then it is explained validation result of the expert team, the first is material expert validation can be seen in table 3 below.

Table 3. Validation Result of Material Expert

\begin{tabular}{|c|c|c|}
\hline Assessment Indicator & Validation 1 & Validation 2 \\
\hline $\begin{array}{l}\text { Compatibility of material with Semester } \\
\text { Learning Plan }\end{array}$ & 5 & 7 \\
\hline Accurateness of material & 11 & 17 \\
\hline Update of material & 6 & 9 \\
\hline Encourage curiosity & 6 & 8 \\
\hline Presentation technique & 4 & 6 \\
\hline Presentation completeness & 10 & 14 \\
\hline Learning presentation & 8 & 11 \\
\hline Order of thought flow & 4 & 5 \\
\hline Characteristic of Collaborative Learning & 10 & 13 \\
\hline Evaluation system & 3 & 4 \\
\hline$\sum \mathrm{x}$ & 69 & 94 \\
\hline $\mathrm{N}$ & 25 & 25 \\
\hline $\bar{x}$ & 2,76 & 3,76 \\
\hline
\end{tabular}




\begin{tabular}{|r|c|c|}
\hline Score percentage & $55,20 \%$ & $75,20 \%$ \\
\hline Category & Quite & Good \\
\hline
\end{tabular}

The second validation was conducted by language expert that can be seen in this table 4 .

Table 4. Result Validation of Language Expert

\begin{tabular}{|l|c|}
\hline \multicolumn{1}{|c|}{ Assessment Indicator } & Validation 1 \\
\hline Simple & 14 \\
\hline Communicative & 4 \\
\hline Dialogical and interactive & 8 \\
\hline Compatibility with students' development & 9 \\
\hline Compatibility with Kaidah Bahasa Indonesia & 19 \\
\hline \multicolumn{1}{|c|}{$\mathrm{N}$} & 54 \\
\hline $\bar{x}$ & 12 \\
\hline Score percentage & 4,5 \\
\hline Category & Very Good \\
\hline
\end{tabular}

The last validation was conducted by media expert, the result of media expert validation that can be seen in table 5 .

Table 5. Result Validation of Media Expert

\begin{tabular}{|c|c|}
\hline Assessment Indicator & Score \\
\hline Size of teaching material & 4 \\
\hline Cover design & 31 \\
\hline Teaching material design & 14 \\
\hline Media of Ispring Presenter & 14 \\
\hline$\sum \mathrm{X}$ & 63 \\
\hline $\mathrm{N}$ & 17 \\
\hline $\bar{x}$ & 3,705882 \\
\hline Score percentage & $74, \%$ \\
\hline Category & Good \\
\hline
\end{tabular}

Besides, result validation of the expert team, this research produces a result of students' response questionnaire related to teaching material of transportation problem in the linear program. The result of students' response questionnaire can be seen in table 6 below.

Table 6. Result of Students' Response Questionnaire

\begin{tabular}{|c|l|c|c|}
\hline No & Component & Percentage & Criteria \\
\hline 1 & Display & 82,85 & Very Good \\
\hline 2 & $\begin{array}{l}\text { Material } \\
\text { Presentation }\end{array}$ & 83,33 & Very Good \\
\hline 3 & Advantage & 77,08 & Good \\
\hline \multicolumn{2}{|c|}{ Average } & 81,09 & Very Good \\
\hline
\end{tabular}


Discussion in development research of teaching material of transportation problem in the linear program through collaborative learning assisted iSpring presenter is that research was conducted in semester IV of study program Mathematics in STKIP Muhammadiyah Kotabumi with a number of students is 13 students with the reason that linear program subject was lectured in that semester.

The advisability of teaching material is measured based on the validation of material, language, and media expert. Validation assessment questionnaire is adapted from an instrument of BNSP [8]. In table 3 is seen that each assessment indicator consists of aspect component which is assessed. Compatibility of material with Semester Learning Plan, accurateness of material, an update of material, and encouraging curiosity are aspect components of content advisability. Then presentation technique, presentation completeness, learning presentation and order of thought flow are aspect components of material advisability. Next characteristic of collaborative learning and evaluation system are learning approach components. The last component is modification result in this research to cover assessment indicators related to learning model which is implemented in the learning process using teaching material of transportation problem. The whole of validation components of a material expert is assessed with the resulting percentage $75,20 \%$ as a good category.

Validation result of Language Expert is $90 \%$ as a very good category. Assessment indicator of simple has appropriateness assessment item of sentence structure, the effectiveness of the sentence, and term formal very good. Then communicative is same with the legibility of deep message by a reader that is student very good. Dialogical and interactive is aimed for teaching material can motivate students and encourage critical think. Teaching material has appropriateness with intellectual development and students' emotion. The last aspect of teaching material has appropriateness of grammar, appropriateness of spelling, consistency in using term and symbol and sign.

Validation result of media expert explained that teaching material has appropriate size teaching material with ISO standard, cover design has a good point of view, teaching material design is appropriate with the content of teaching material, harmony, and completeness of layout and good content typography. ISpring media becomes one of the assessment components to support good learning with the flash format and add-ins power point.

Based on the result of students' response questionnaire test, the advisability of teaching material of transportation problem in the linear program got percentage $81,09 \%$ as a very good category. Questionnaire arranger components are display, presentation of material, an advantage. In each component has each detail. Display component got percentage $82,85 \%$ as a very good category. It is because of very good text clarity and illustration or picture with the very appropriate material. Presentation of material component got percentage $83,33 \%$ as a very good category. It shows that students got convenience in understanding material, teaching material has appropriateness in using sign and symbol, teaching material has completeness and systematical appropriateness presentation and there is compatibility of example with material taught. In advantage component, teaching material got percentage $77,08 \%$ as a good category. Explanation of advantage is showing students' convenience learning. In addition, significantly there is an enhancement of students' learning motivation and interest using teaching material of transportation problem in the linear program.

\section{Conclusion}


According to development research, it can be concluded that this research produces teaching material entitled "Bahan Ajar Masalah Transportasi Program Linear". It is based on advisability test of questionnaire result percentage of students' response is $81,785 \%$ as a Good category. Then supported from validation result of media is with the percentage $74 \%$ as a good category, validation of language expert is with the percentage $90 \%$ as a very good category, and validation of material expert is with the percentage $75,20 \%$ as a good category. When all categories are more than equals to good then teaching material is proper to be used. in addition, this development research produces interactive learning media that is flash which comes from iSpring presenter that is used.

\section{References}

[1] Ni Ketut Kertiasih, "Penggunaan Metode Transportasi Dalam Program Linier Untuk Pendistribusian Barang,” JPTK. UNDIKSA, Vol. 6, No. 2,pp 27-35, Juli 2009. 
[2] Rudi Alfiyansah, “ Penggunaan Media Pembelajaran Ispring Presenter Untuk Meningkatkan Motivasi dan Hasil Belajar Pada Mata Kuliah Keperawatan Dasar Nutrisi," PEDAGOGIA: Jurnal Ilmu Pendidikan.

[3] Morgi Dayana,"Pengaruh Aktivitas Pembelajaran dengan metode Collaborative Learning Terhadap Perkembangan Sosial Emosional Anak," Jurnal Penlitian Lampung.

[4] Borg, W. R. \& Gall, M. D, “ Educational research: An introduction (4th ed.)". New York, NY: Longman, pp 755.

[5] Sugiyono,"Metode Penelitian pendidikan R\&D". Bandung: Alfabeta.

[6] Budiyono,"Metodologi Penelitian Pendidikan". Surakarta: UNS Press.

[7] Riduwan," Skala Pengukuran Variabel-Variabel Penelitian". Bandung: Alfabeta.

[8] BNSP, "Instrumen Penilaian Buku Teks Pelajaran Ekonomi (Buku Siswa) Sekolah Menengah Atas/Madrasah Aliyah". Jakarta:Badan Standar Nasional Pendidikan 